\title{
Ernst Haeckel (1834-1919): The German Darwin and his impact on modern biology
}

\author{
Ulrich Kutschera ${ }^{1} \cdot$ Georgy S. Levit ${ }^{1} \cdot$ Uwe Hossfeld $^{2}$
}

Received: 15 November 2018 / Accepted: 15 January 2019 / Published online: 24 February 2019

c) Springer-Verlag GmbH Germany, part of Springer Nature 2019

\begin{abstract}
The year 2019 marks the 100th anniversary of the death of Ernst Haeckel, a German zoologist, artist, and philosopher of science, who defended and supplemented Charles Darwin's system of theories regarding the mechanisms of biological evolution. We briefly recapitulate Haeckel's remarkable career and reproduce the Laudatio read by the President of the Linnean Society of London (1 July 1908), when Haeckel was awarded the Darwin-Wallace Medal. Finally, we summarize the importance of Haeckel's original concepts, insights, and theories with reference to our current knowledge in the areas of evolutionary biology, molecular phylogenetics, systematic zoology, and philosophical issues today.
\end{abstract}

Keywords Ernst Haeckel · Charles Darwin · Darwin-Wallace Medal · Evolution

\section{Introduction}

The German biologist and artist Ernst Heinrich Philipp August Haeckel (1834-1919) (Fig. 1) was a key figure during the early years of the "First Darwinian revolution", a time period when the foundation for the development of our modern evolutionary view of the biosphere was laid. Born 16 February 1834 in Potsdam, Haeckel studied medicine at the Universities of Berlin, Würzburg, and Vienna, after graduation from the Domgymnasium Merseburg. When Haeckel was 23 years old (1857), he earned his "Dr. med." and started to work as a physician. However, after contact with suffering patients, he soon gave up practicing medicine.

This article is a contribution to the Special Issue Ernst Haeckel (1834-1919): The German Darwin and his impact on modern biology_Guest Editors: U. Hossfeld, G. S. Levit, U. Kutschera.

Ulrich Kutschera

kut@uni-kassel.de

Georgy S. Levit

georgelevit@gmx.net

Uwe Hossfeld

uwe.hossfeld@uni-jena.de

1 Institute of Biology, University of Kassel,

Heinrich-Plett-Strasse 40, 34132 Kassel, Germany

2 Biology Education Research Group,

Friedrich-Schiller-University of Jena, Bienenhaus - Am

Steiger 3, 07743 Jena, Germany
After 4 years of experimental work on the systematics of the Radiolaria, Haeckel earned his habilitation at the University of Jena (1861) and became a Privatdozent (lecturer). When his first major monograph on the systematics of the Radiolaria was published (Haeckel 1862), he was promoted to extraordinary (a. o.) professor. Three years later, Haeckel earned a doctorate in zoology (Dr. phil.) at the Faculty of Philosophy (13 July 1865). In the same year, a. o. Prof. Dr. med. Dr. phil. Ernst Haeckel was appointed to the Lehrstuhl (chair) of zoology at the University of Jena. Here, he continued to work as a full (o.) professor until his retirement (Emeritierung) on 1 April 1909. Accordingly, Haeckel was 75 years old when he gave up his duties as an academic teacher, after almost 50 years in office at his alma mater. Haeckel published approximately 700 journal and newspaper articles and 18 major books (Haeckel 1862, 1866, 1868, 1872, 1874, 1878, 1879/1881, 1883, 1894/1896, 1899, 1899/1904, 1901, 1902, 1904, 1905, 1907, 1908, 1917). His artwork, comprised of more than 100 illustrations and watercolours, was compiled and published in his Kunstformen der Natur (Haeckel 1899/1904). Ernst Haeckel died on 9 August 1919, at age 85, in his Villa Medusa in Jena (Hossfeld 2010, 2016). 


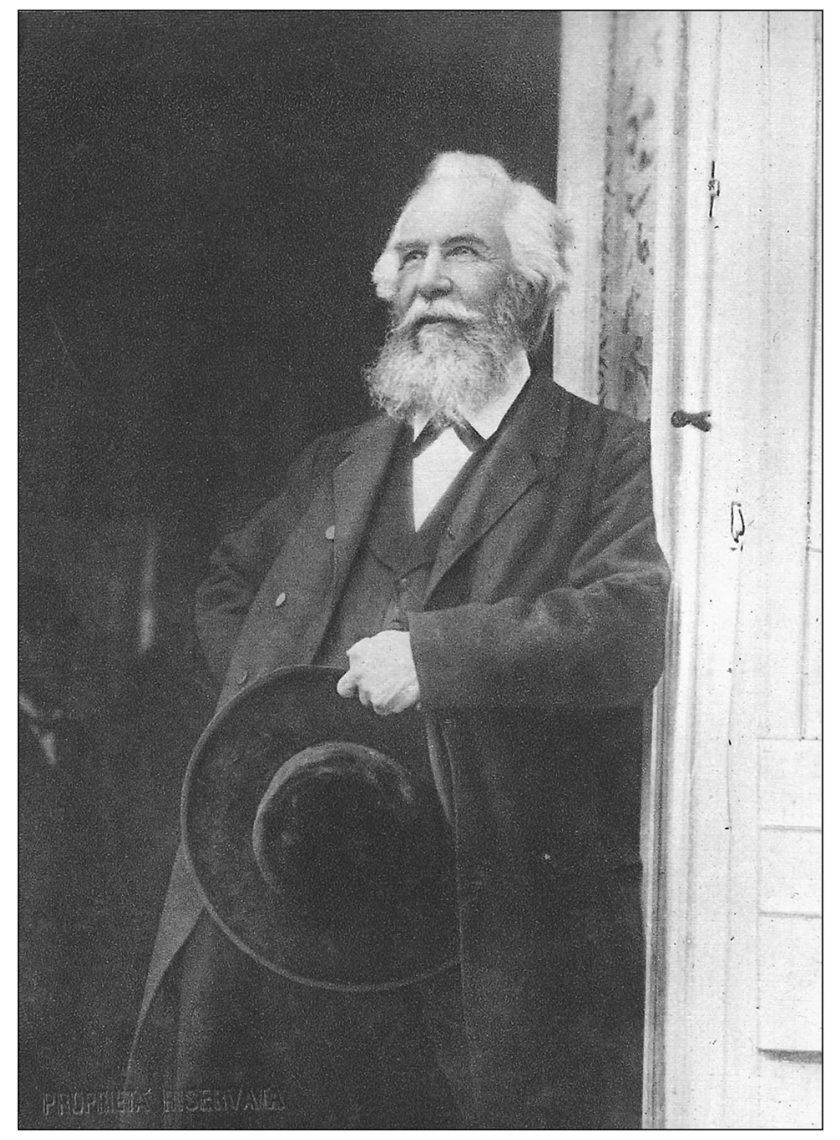

Fig. 1 Ernst Haeckel (1834-1919), the "German Darwin". Photograph taken in 1904 during a symposium at the University of Genoa, Italy. Courtesy of Uwe Hossfeld, Jena

\section{The German Darwin}

Despite some attractive offers from other major German universities (e.g. Berlin) to take over a vacant full professorship, Haeckel remained in Jena (Fig. 2) to continue his work as a researcher, artist, philosopher of science, and academic teacher. However, during these ca. 50 years in Jena, he travelled a lot, $1859 / 60$ to Italy, 1866 to the Canary Islands, 1866 to Norway, 1870 to the Orient, 1875 to Corsica, 1876 to Scotland, 1878 to Brittany, 1887 again to the Orient, 1890 to Algiers, and 1897 to Russia. In addition to these "short trips", Haeckel visited tropical regions (in 1881, Ceylon; 9 years later, Java and Sumatra), where he not only explored nature, but was also an active artist.

In April 1860, when he came back from Italy, the then 26-year-old Haeckel read with great interest the German version of the 2nd ed. of Charles Darwin's On the Origin of Species (Darwin 1860). The young naturalist was immediately impressed to such an extent that he defended Darwin's system of theories against fierce attacks from some of his colleagues (Kutschera 2009). Haeckel, who discovered and described hundreds of species, coined key terms, such as ecology and ontogeny/phylogeny, and was well known for his popularized version of the "recapitulation theory" during embryonic development of animals. Moreover, in his Generelle Morphologie, Haeckel (1866) concluded that all complex forms of life on Earth originated from bacteria. This was a remarkable insight that, decades later, laid the foundation for the now widely accepted "two primary domains of life-model" describing the origin of the first eukaryotic cell (Kutschera 2016).
Fig. 2 Jena in the year 1874. Watercolour by Ernst Haeckel (Archive of the Ernst-HaeckelHaus, Friedrich-Schiller-University Jena, Germany)

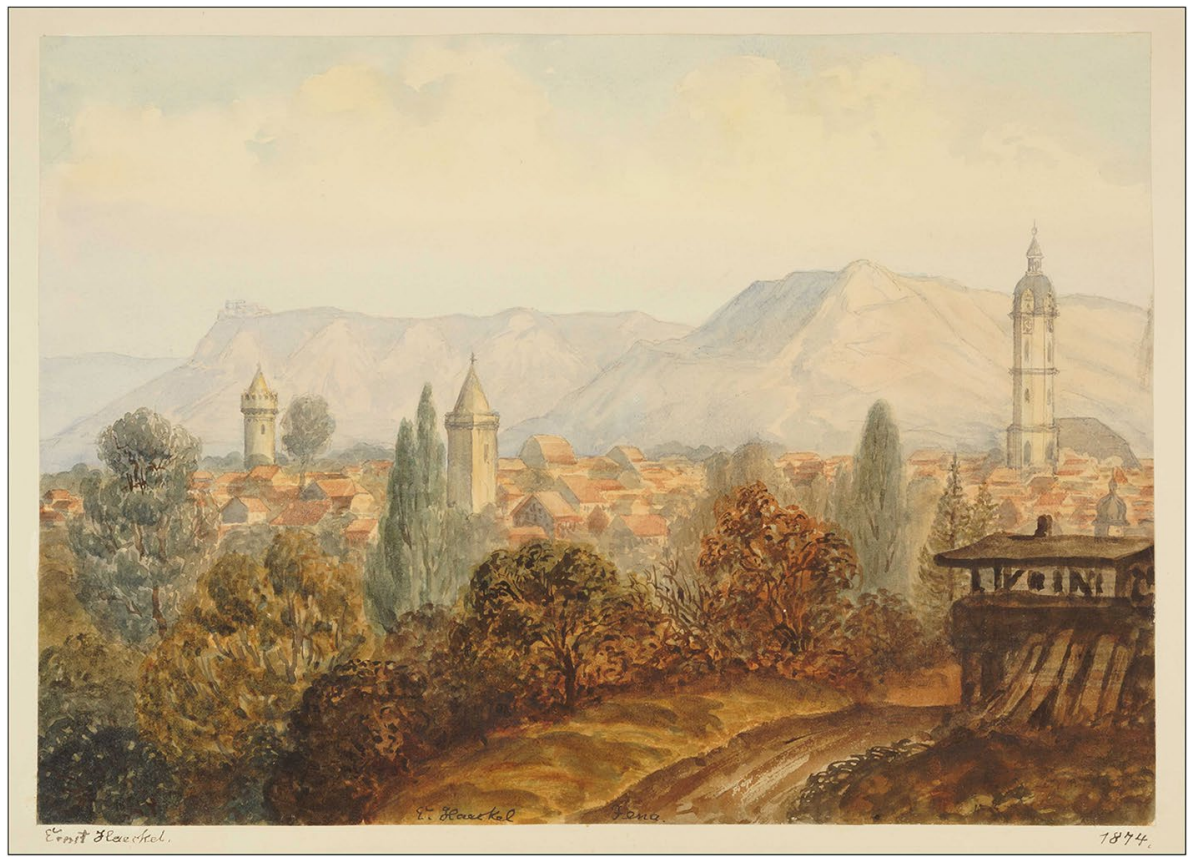


Based on his scientific insights, Haeckel was a lifelong supporter of the Darwinian principle of descent with modification, later called "evolution" (Hossfeld and Olsson 2003; Olsson et al. 2017). This devotion to a naturalistic (evolutionary) world view, notably Haeckel's depiction of all forms of life in splendidly designed phylogenetic trees (Kutschera 2011, 2016; Hossfeld and Levit 2016; Hossfeld et al. 2017), resulted in an "honorary title": he was soon called "The German Darwin" (Aveling 1886). As described below, Darwin and Haeckel were close personal friends who treated each other with great respect and admiration.

\section{Haeckel as a recipient of the Darwin-Wallace Medal}

In June 1907, Haeckel gave a talk on the topic "Das Menschen-Problem und die Herrentiere von Linné" (The Human Problem and Linné's Pimates) in the Volkshaus in Jena, and 1 year later (1 July 1908), the German biologist received the Linnean Society of London's prestigious "Darwin-Wallace Medal". The other six awardees were British naturalist Alfred Russel Wallace (1823-1913), the botanist Joseph Dalton Hooker (1817-1911), the geneticist Francis Galton (1822-1911), the zoologist Edwin Ray Lancester (1847-1929), and two of Haeckel's German peers: the zoologist August Weismann (1834-1914) and the botanist Eduard Strasburger (1844-1912). The president of the society, botanist Dukinfield H. Scott (1854-1934), read the following Laudatio dedicated to Ernst Haeckel (Fig. 3):

"The President: We much regret that our distinguished Foreign Member and Linnean Medallist, Professor Haeckel, is prevented by his academic duties from being present to-day, but Herr von Bethmann-Hollweg, of the German Embassy, has kindly attended to receive the medal on his behalf. Prof. Haeckel, a personal friend of Mr. Darwin's, who paid more than one visit to him at Down, has been the great apostle of the Darwin-Wallace theory in Germany. His advocacy of the doctrine of Evolution in his Monograph of the Radiolaria (1862), first brought it before the attention of German men of Science; his enthusiastic and gallant advocacy ever since has chiefly contributed to its success in that country.

Mr. Darwin, in 1873, wrote to Prof. Haeckel, 'You will do a wonderful amount of good in spreading the doctrine of Evolution, supporting it as you do, by so many original observations'.

A brilliant writer and investigator, author of a number of classical Zoological Monographs, Prof. Haeckel has become especially distinguished for his writings on Phy- logeny, above all the great ,Generelle Morphologie", and for his popular works, such as the ,Schöpfungsgeschichte', which have exercised a great and wide influence on the present generation.

The stimulating vigour of his style roused a keen and general interest in evolution in the early days of Darwinism. His phylogenetic pedigrees have played a useful and important part as aids to the imagination and as familiarizing the mind with the idea of descent, at a time when the evolutionary conception was still obscure. They are intended rather as artistic endeavours to picture what happened in the past than as dogmatic statements of historical sequences. Haeckel, so distinguished in the laboratory, has, like Darwin, Wallace, and Hooker, a strongly developed naturalist side, shown by his scientific travels, in the Canaries, Ceylon, and elsewhere. He, too, is a thorough Darwinian, who has remained loyal to the principle of natural selection.

A man of worldwide reputation, the leader on the Continent of the 'Old Guard' of evolutionary biologists, Prof. Haeckel is one whom our society delights to honour, and I ask you to transmit to him the Darwin-Wallace Medal, as a testimony of our admiration and respect" (Fig. 4).

In these kind words, the president of the Linnaean Society stressed that Haeckel was not only an outstanding scientist, who promoted Darwin's work in Germany and supplemented his concepts on the modes and mechanisms of organismic evolution considerably, but was also an artist with outstanding abilities. Most importantly, it appears that Darwin also had a great deal of respect for Haeckel as Darwin and Haeckel exchanged more than 150 letters, over a period of about 20 years, and Haeckel visited Darwin three times at his Down House (1866, 1876, 1879). Moreover, this Laudatio clearly documents that Haeckel ranks among the most important evolutionary biologists and philosophers of the natural sciences in the nineteenth and in the beginning of twentieth century.

It should be noted that Haeckel was the first to use the term "World War I" shortly after this catastrophic conflict broke out, in a statement published on 20 September 1914 in the journal Indianapolis Star (Shapiro 2006). Later in his life, he devoted most of his time to philosophical-religious issues, such as the establishment and spread of his naturalistic-spiritualistic world view, which he described as "Monism" (Haeckel 1899).

\section{Haeckel's lasting legacy}

As summarized above, Ernst Haeckel was a key figure in the history of biology. However, he was not only a creative naturalist and artist, but also a popularizer of science and fighter against dogmatic religious views (Christianity, Judaism, Muslimism) (Haeckel 1899). With the development and 
Fig. 3 Portraits of Charles Darwin (1809-1882) and Ernst Haeckel, combined with a copy of the first paragraphs taken from the Laudatio, which was read by the President of the Linnean Society of London on 1 July 1908. Adapted from Scott (1908)
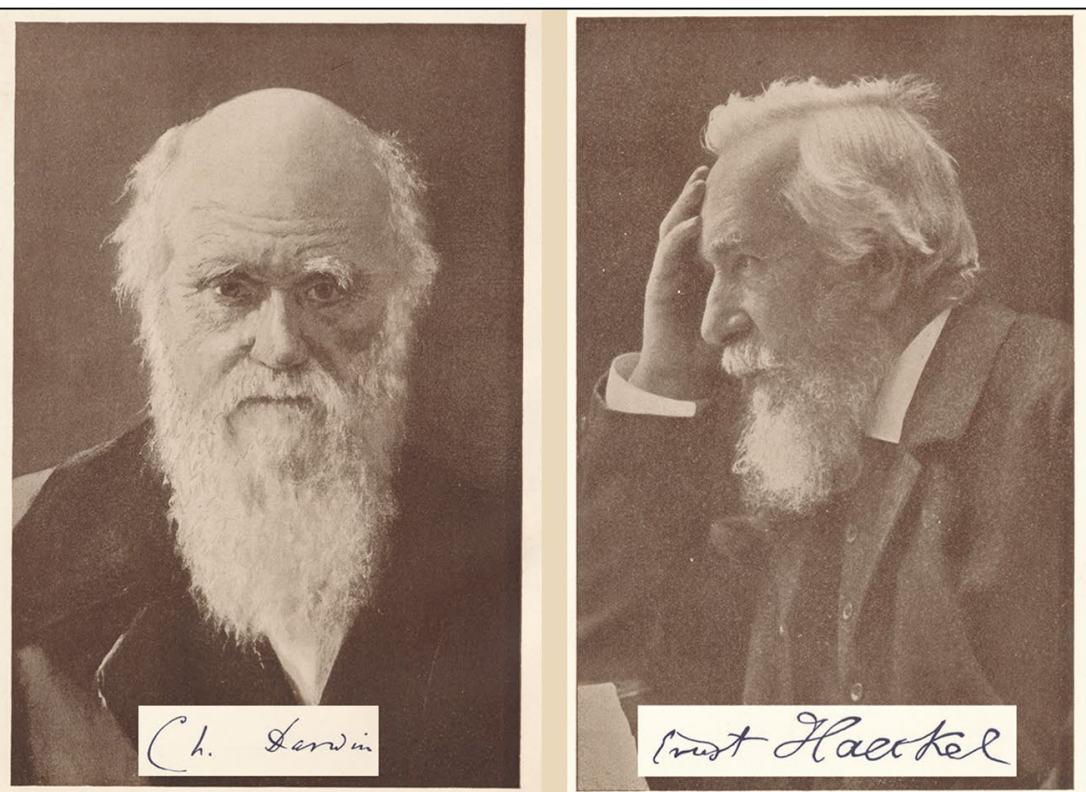

The President : We much regret that our distinguished Foreign Member and Linnean Medallist, Professor Hacckel, is prevented by his academic duties from being present to-day, but Herr von Bethmann-Hollweg, of the German Embassy, has kindly attended to receive the medal on his behalf.

Prof. Haeckel, a personal friend of Mr. Darwin's, who paid more than one visit to him at Down, has been the great apostle of the Darwin-Wallace theory in Germany. His advocacy of the doctrine of Evolution in his Monograph of the Radiolaria (1862), first brought it before the attention of German men of Science; his enthusiastic and gallant advocacy ever since has chiefly contributed to its success in that country.

Mr. Darwin, in 1873, wrote to Prof. Haeckel, "You will do a wonderful amount of good in spreading the doctrine of Evolution, supporting it as you do, by so many original observations." ..................... our admiration and respect. spread of his "Monistic world view", however, he promoted ideas that have been sharply criticized, not only by religious people, but also by moderate thinkers and some of his fellow scientists.

In this Special Issue, 13 original articles are published that document Ernst Haeckel's legacy that continues to influence biological thinking, even in the 100th year of his death (1919). Our Haeckel Issue is divided into four parts:

1. Science education. E. Watts et al. discuss "Ernst Haeckel's contribution to Evo-Devo and scientific debate". In this context, they re-evaluate Haeckel's controversial illustrations in US textbooks with reference to creationist accusations. U. Hossfeld et al. analyse "Haeckel's embryology in biology textbooks" published during the era of the "German Democratic Republic, 1951-1988". They present a short history of the visualization of Haeckel's "Biogenetic Law" and his "Gastraea-Theory", as detailed in the classical textbooks referred to by the authors.

2. Haeckel-reception in Russia. E. Kolchinsky discusses the "Russian editions of Haeckel's works" and outlines the spread of their perception in this country. Notably, the author highlights Russian anti-religious propaganda 


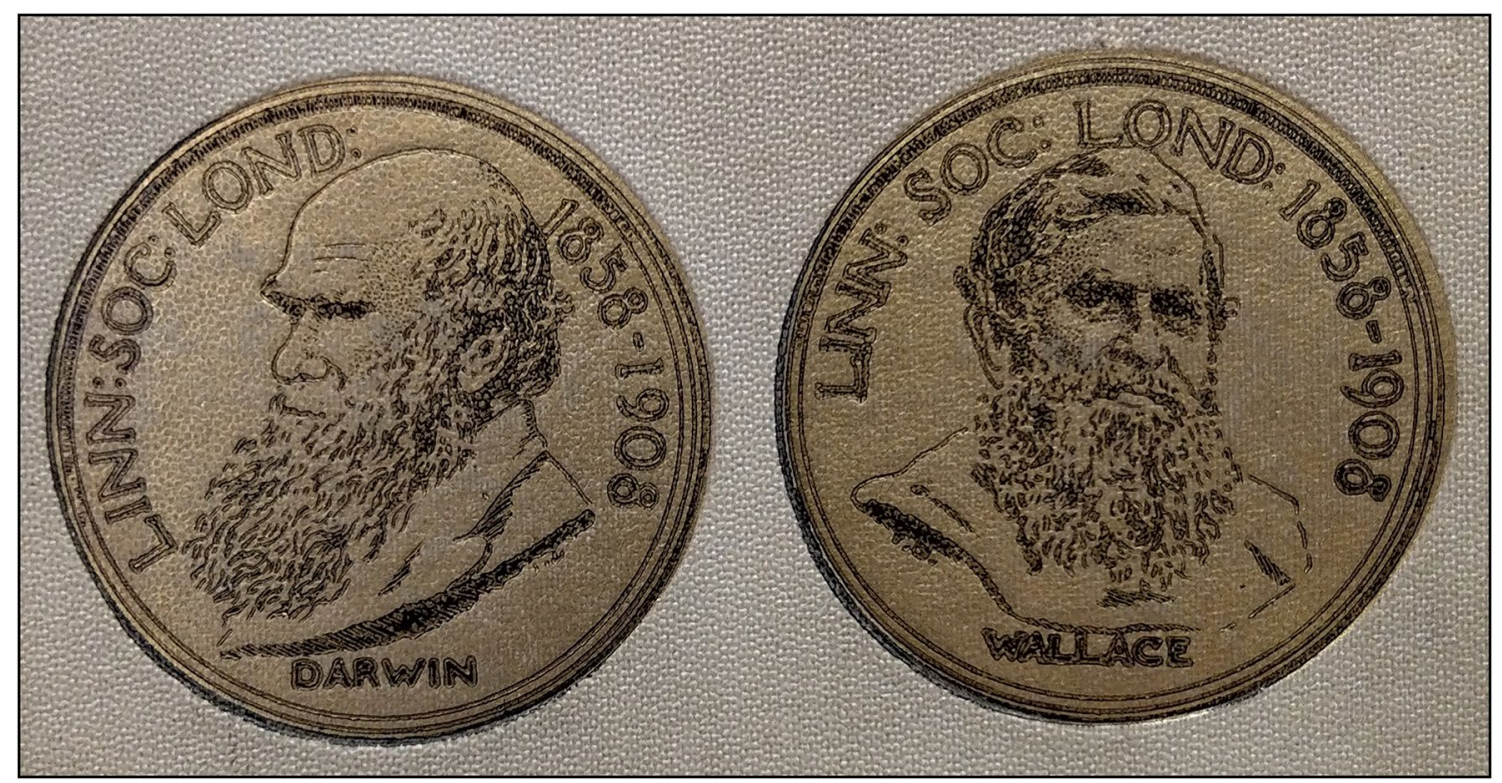

Fig. 4 Cover image of the book on the Darwin-Wallace celebration, showing both sides of the Darwin-Wallace Medal, reproduced from the original monograph. Photo: P. Bock; adapted from Scott (1908)

with respect to Haeckel's work that was misused to substantiate Lysenkoism. In an accompanying article, E. Kolchinsky and G. S. Levit describe the "Reception of Haeckel in pre-revolutionary Russia and his impact on evolutionary theory". The authors conclude that, although Haeckel's ideas influenced several important Russian evolutionists (for instance, Konstantin Mereschkovsky, 1855-1921), his speculative hypotheses and his attempts to develop Darwinism into a world view found little support among these life scientists. A third paper in this section by A. L. Rizhinashvili, entitled "Ernst Haeckel's 'ecology' in Russia during the first half of the 20 century", details the impact of the "German Darwin's" views on organismic interactions and evolutionary theory in this country.

3. Haeckel's followers. In the first study of this section, G. Finkelstein describes the relationship between "Haeckel and du Bois-Reymond". He concludes that the physiologist Emil du Bois-Reymond (1818-1896) and Ernst Haeckel should be interpreted as "Rival German Darwinists". N. A. Rupke analyses "The break-up between Darwin and Haeckel" during the early decades of the 20th century. He argues that the cause was not based on scientific issues, but rather due to political and nationalistic influences, such as Marxism and the emergence of Nazi ideology. L. Olsson and U. Hossfeld studied the "Haeckel-reception in Sweden" and documented how the ideas of the "German Darwin" were received by leading scientists and students in this part of Scandinavia. In a last contribution to this section, U. Kutschera and T. Hoppe studied "Plasmodial slime molds and the evolution of microbial husbandry", with reference to Haeckel's work on myxomycetes and his concept of ecology. The authors conclude that the classical drawings of myxomycetes published by Haeckel are still unsurpassed depictions of these eukaryotic microbes and that plasmodial slime moulds may have evolved a kind of "farming symbiosis".

4. The influence of Haeckel on disciplines outside the biological sciences. In this last series of papers, A. S. Reynolds discusses "Ernst Haeckel and the philosophy of sponges". The author argues that Haeckel's Gastraea theory, explaining the monophyletic origin of the Metazoa, was inspired by the simple structure of a spongelike (hypothetical) embryo. O. Rieppel analyses "The concept of the 'organic individual' in Haeckel's writings" and concludes that these philosophical considerations provided to him a strong proof for the validity of Darwin's theory of descent with modification. J. R. Jungck et al. discuss the influence of Haeckel's "Art forms in nature" (notably his depictions of microscopic protozoans) on various artists (inclusive of sculptors, architects, and designers/film-makers). Under the title "Radiolaria from Haeckel to Blaschka to 3D nanotomography, quantitative image analysis, evolution, and contemporary art", the authors summarize Haeckel's legacy with reference to biomimetic design and related issues. Finally, I. G. Stewart et al. investigated the relationship between "Evolutionary ethics and Haeckelian monism" with reference to Heinrich Schmidt's (18741935) book Harmonie, wherein the author presents a "monistic ethics". Stewart et al. conclude that Haeckel's 
and Schmidt's versions of monism were not accepted as ethical guidelines by the National Socialists, who nevertheless attempted to misuse some of Haeckel's statements to support their fascist ideology.

Taken together, the major objective of the Guest Editors was to explore lesser-known aspects of Haeckel's scholarly legacy and to demonstrate his national and international impact on biology, philosophy, the arts, and ethics.

\section{Conclusions and outlook}

This Special Issue does not present a complete view of Haeckel's output, because our state of knowledge is not yet complete. We only take one further step towards the goal of presenting a complete picture of all aspects of Haeckel's bio-philosophical writings and his influence as an artist. We hope that, sometime in the future, there will be a "Haeckelindustry", similar to the "Darwin-frenzy" that reached its last peak in 2009, and continues to overshadow the work of other important biologist. Finally, we want to stress that Haeckel's influence was, on the one hand, exceptionally broad, and, on the other hand, controversial, so that this key figure in the history of biology will continue to remain of interest for philosophers of science and biologists alike.

Acknowledgements We thank Prof. Juergen Jost (MPI Mathematics in the Sciences, Leipzig, Germany) for editorial work and constructive comments on all contributions that are published in this Special Issue.

\section{References}

Aveling E (1886) Die Darwinsche theorie. Verlag von J. H. W. Dietz, Stuttgart

Darwin C (1860) On the origin of species by means of natural selection, or, the preservation of favoured races in the struggle for life, 2nd edn. John Murray, London

Haeckel E (1862) Die Radiolarien (Rhizopoda Radiaria). Eine Monographie. Theil 1: Mit einem Atlas von 35 Kupfertafeln, 1862. Theil 2: Grundriss einer allgemeinen Naturgeschichte der Radiolarien. Mit 64 Tafeln, 1887. Theile 3 und 4: Die Acantharien und Phaeodarien oder Actipyleen und Cannopyleen Radiolarien. Mit 42 Tafeln, 1888. Verlag Georg Reimer, Berlin

Haeckel E (1866) Generelle Morphologie der Organismen. Allgemeine Grundzüge der organischen Formen-Wissenschaft, mechanisch begründet durch die von Charles Darwin reformierte Descendenztheorie. Band 1. Allgemeine Anatomie der Organismen, Band 2. Allgemeine Entwickelungsgeschichte der Organismen. Verlag Georg Reimer, Berlin

Haeckel E (1868) Natürliche Schöpfungsgeschichte. Gemeinverständliche wissenschaftliche Vorträge über die Entwickelungslehre im Allgemeinen und diejenige von Darwin, Goethe und Lamarck im Besonderen, über die Anwendung derselben auf den Ursprung des Menschen, und andere damit zusammenhängende Grundfragen der Naturwissenschaft. Verlag Georg Reimer, Berlin (12. Auflage 1920)
Haeckel E (1872) Die Kalkschwämme. Eine Monographie. In zwei Bänden Text und einem Atlas mit 60 Tafeln Abbildungen. Verlag Georg Reimer, Berlin

Haeckel E (1874) Anthropogenie oder Entwickelungsgeschichte des Menschen. Gemeinverständliche wissenschaftliche Vorträge über die Grundzüge der menschlichen Keimes- und StammesGeschichte. Wilhelm Engelmann, Leipzig (6. Auflage 1910)

Haeckel E (1878) Das Protistenreich. Eine populäre Übersicht über das Formengebiet der niedersten Lebewesen. Mit einem wissenschaftlichen Anhange: System der Protisten. Ernst Günther's Verlag, Leipzig

Haeckel E (1879/1881) Das System der Medusen. 2 Teile. 1. System der Craspedoten, 2. System der Acraspeden. Verlag Gustav Fischer, Jena

Haeckel E (1883) Indische Reisebriefe. Gebrueder Paetel, Berlin (4. Auflage 1903)

Haeckel E (1894/1896) Systematische Phylogenie. Entwurf eines natürlichen Systems der Organismen aufgrund ihrer Stammesgeschichte. 3 Bde. 1. Teil: Systematische Phylogenie der Protisten und Pflanzen, 1894. 2. Teil: Systematische Phylogenie der wirbellosen Thiere (Invertebrata), 1896. 3. Teil: Systematische Phylogenie der Wirbelthiere (Vertebrata), 1895. Verlag Georg Reimer, Berlin

Haeckel E (1899) Die Welträthsel. Gemeinverständliche Studien über monistische Philosopie. Emil Strauß, Bonn (11. Auflage 1919)

Haeckel E (1899/1904) Kunstformen der Natur. 100 Tafeln in 10 Lieferungen. Bibliographisches Institut, Leipzig und Wien

Haeckel E (1901) Aus Insulinde. Malayische Reisebriefe. Emil Strauss, Bonn (3. Auflage Leipzig 1923)

Haeckel E (1902) Gemeinverständliche Vorträge und Abhandlungen aus dem Gebiete der Entwickelungslehre. Emil Strauss, Bonn

Haeckel E (1904) Die Lebenswunder. Gemeinverständliche Studien über Biologische Philosophie. Ergänzungsband zu dem Buche über die Welträthsel. Alfred Kroener Verlag, Stuttgart. (5. Auflage 1925)

Haeckel E (1905) Wanderbilder: Die Naturwunder der Tropenwelt - Ceylon und Insulinde. Nach eigenen Aquarellen und Ölgemälden. Serie 1 und 2: Die Naturwunder der Tropenwelt, Ceylon und Insulinde. Koehler'sche Verlagsbuchhandlung, Gera-Untermhaus

Haeckel E (1907) Das Menschen-Problem und die Herrentiere von Linné. Neuer Frankfurter Verlag, Frankfurt a. M

Haeckel E (1908) Unsere Ahnenreihe (Progonotaxis hominis). Kritische Studien über Phyletische Anthropologie. Festschrift zur 350-jährigen Jubelfeier der Thüringischen Universität Jena und der damit verbundenen Uebergabe des Phyletischen Museums am 30. Juli 1908. Verlag Gustav Fischer, Jena

Haeckel E (1917) Kristallseelen - Studien über das anorganische Leben. Alfred Kroener Verlag, Leipzig

Hossfeld U (2010) Ernst Haeckel. Orange-Press, Freiburg im Breisgau

Hossfeld U (2016) Geschichte der biologischen Anthropologie in Deutschland. Von den Anfängen bis in die Nachkriegszeit. 2. Auflage. Franz Steiner Verlag, Stuttgart

Hossfeld U, Levit GS (2016) 'Tree of life' took root 150 years ago. Nature 540:38

Hossfeld U, Olsson L (2003) The road from Haeckel. The Jena tradition in evolutionary morphology and the origin of "Evo-Devo". Biol Philos 18:285-307

Hossfeld U, Levit GS, Watts E (2017) The first Darwinian phylogenetic tree of plants. Trends Plant Sci 20:99-102

Kutschera U (2009) In the wake of Charles Darwin and beyond: a tribute to Ernst Mayr. Evo Edu Outreach 2:564-566

Kutschera U (2011) From the scala naturae to the symbiogenetic and dynamic tree of life. Biol Direct 6(33):1-20

Kutschera U (2016) Haeckel's 1866 tree of life and the origin of eukaryotes. Nat Microbiol 1:16114 
Olsson L, Levit GS, Hossfeld U (2017) The „Biogenetic Law“ in zoology: from Ernst Haeckel's formulation to current approaches. Theory Biosci 136:19-29

Scott DH (ed) (1908) The Darwin-Wallace Celebration, held on Thursday, 1st July, 1908, by the Linnean Society of London. Burlington House, Piccadilly

Shapiro FR (ed) (2006) The yale book of quotations. Yale University Press, New Haven
Publisher's Note Springer Nature remains neutral with regard to jurisdictional claims in published maps and institutional affiliations. 